Popovoy ta in., 2014 - Istoricheskaya urbanistika: teoriya i praktika: uchebnik dlya vuzov [Historical urban studies: theory and practice: a textbook for universities] / pod red. Popovoy N.A., Ponomarevoy M.A. Rostov-na-Donu: Izdatelstvo Yuzhnogo federalnogo universiteta, 2014. 320 s. [in Russian]

Rydzyunskij, 1983 - Rydzyunskij P. G. Krestyane i gorod v kapitalisticheskoj Rossii vtoroj poloviny XIX veka [Peasants and the city in capitalist Russia in the second half of the XIX century]. Moskva, 1983. 272 s. [in Russian] Shilova, 2010 - Shilova O. N. Povsednevnaya zhizn provincialnogo goroda: k istoriografii voprosa [Everyday life of a provincial town: on the historiography of the question] // Vestnik Tomskogo universiteta. 2010. №4 (12). S. 124-126. [in Russian]

Ekzemplyarskij, 1958 - Ekzemplyarskij P. M. Istoriya goroda Ivanova [History of the city of Ivanovo]: V 2 ch. Ivanovo, 1958. 396 s.[in Russian]

УДК 378.018.8:373.011.3-051:378.4(477.46)УДПУ"1930/2020"

олена ДЖАГУНОВА, orcid.org/0000-0003-2129-9761 кандидат історичних наук, викладач кафедри історії України Уманського державного педагогічного університету імені Павла Тичини

(Украӥна, Умань)

o.dzhagunova@udpu.edu.ua

\title{
ПРОФЕСІЙНА ПІДГОТОВКА ВЧИТЕЛІВ У СИСТЕМІ ПЕДАГОГІЧНОЇ ОСВІТИ УКРАЇНИ 1930-2020 РР. НА ПРИКЛАДІ УМАНСЬКОГО ПЕДАГОГІЧНОГО УНІВЕРСИТЕТУ: ІСТОРІОГРАФІЧНИЙ АСПЕКТ
}

У статті висвітлено історичні та історіографічні дослідження, які стосуються розвитку та реформування вищьӧ педагогічної освіти загалом та Уманського державного педагогічного університету зокрема. Показано узагальнювальні праці вчених з історї вищої педагогічної освіти, про особливості становлення $i$ розвитку педагогічних інститутів та діяльність їх структурних підрозділів $i$ науковопедагогічних кадрів в Україні, зокрема на Черкащині. Проаналізовано прачі, присвячені історії Уманського державного педагогічного університету імені Павла Тичини, де розглянуто окремі періоди діяльності інституту, його підрозділів та окремих викладачів.

Ключові слова: освіта, вища освіта, педагогічні заклади вищої освіти, Уманський педагогічний університет.

Olena Dzhahunova,

Candidate of Historical Sciences

lecturer of Ukraine's History Chair

Pavlo Tychyna Uman State Pedagogical University

(Uman, Ukraine)

o.dzhagunova@udpu.edu.ua

\section{TEACHERS' PROFESSIONAL TRAINING IN THE SYSTEM OF UKRAINIAN PEDAGOGICAL EDUCATION OF 1930-2020 ON THE EXAMPLE OF UMAN PEDAGOGICAL UNIVERSITY: HISTORIOGRAPHICAL ASPECT}

The article covers historical and historiographical researches, which are related to the development and reformation of higher pedagogical education in general and of Uman State Pedagogical University in particular. Generalized works of scholars on the history of higher pedagogical education, peculiarities of the formation, development of pedagogical institutions and the activities of their structural units, research and teaching staff in Ukraine, in particular in Cherkasy region have been examined (the first group). The works dealing with the history of Pavlo Tychyna Uman State Pedagogical University have been analyzed, in which separate periods of the activities of the institute, its subdivisions and separate lecturers have been considered (the second group). 
Besides, in accordance with a problem-chronological principle the first group of studied references may be roughly divided into two stages: 1) 1930-1991; 2) 1991-2014.

At the first stage the published works were party-political, they idealized the policy of the Soviet government in the field of education and its positive achievements. At the second stage the attention of researchers was focused on the problems of the history of higher pedagogical school and its role in a socio-political structure of the society in the conditions of its reformation.

Since the early 90's of the $20^{\text {th }}$ century the situation in the historiography of this thematic group has changed drastically, many unresearched issues have been arisen; the evaluation of events and approaches to their description has changed radically. The concept of "white spots" in history has been coined and in this connection new tasks of historical science have appeared. At this period on the basis of generalization and systematization of new archival materials Ukrainian scholars study various aspects of the development of higher pedagogical education.

The second group includes the works on the history of Pavlo Tychyna Uman State Pedagogical University dealing with certain periods of the activities of the institute, its subdivisions and separate lecturers. There was no objective analysis of the teacher training problems in some educational institutions. The research was conducted mainly in the following directions: 1) the study of a wide range of related issues, which are connected with socialist construction, the development of public education and the formation of new Soviet intelligentsia; 2) the study of separate branches of science and their development; 3) anniversary publications on the history of separate institutions of higher education. University.

Key words: education, higher education, pedagogical institutions of higher education, Uman Pedagogical

Постановка проблеми. Огляд та аналіз історіографії є обов'язковою складовою і одним із основних завдань наукового дослідження. Будь-яка праця розпочинається зі знайомства із науковими працями, де висвітлена зазначена тема. Це дає можливість об’єктивного підходу до вивчення предмету дослідження, окреслити кого нерозглянутих питань та викласти основні погляди щодо проблеми.

Історіографія теми 3 одного боку представлена великою кількістю літератури, що висвітлює загальні проблеми становлення та розвитку системи освіти як в межах колишнього СРСР, так і в Україні, з іншого боку іiі окремо взяті аспекти вивчені недостатньо, про що свідчать спеціальні історіографічні розвідки. Що ж стосується досліджень безпосередньо Уманського закладу вищої освіти, то вони практично відсутні.

Мета статті - висвітлити та проаналізувати історіографію, теми професійної підготовки вчителів у системі педагогічної освіти України 19302020 рр. загалом та в Уманського педагогічного університету, зокрема.

Виклад основного матеріалу. Для характеристики наукової літератури 3 теми дослідження використано хронологічний принцип, за яким виокремлено дві групи публікацій, що концентрують у собі розвиток історико-наукових поглядів радянського періоду та період установлення незалежності України. Вони відрізняються метою та спрямованістю досліджень, колом питань, на яких автори зосереджують увагу, джерельною базою, аналізом позитивних досягнень та недоліків у роботі.

Зважаючи на специфіку теми дослідження, виявлений історіографічний доробок з теми ми умовно систематизували за такими групами:

1) узагальнювальні праці вчених з історії вищої педагогічної освіти, які розкривають особливості становлення і розвитку педагогічних інститутів, висвітлюють діяльність їх структурних підрозділів і науково-педагогічних кадрів в Україні радянській та незалежній;

2) праці, присвячені історії Уманського державного педагогічного 
університету імені Павла Тичини, де розглядаються окремі періоди діяльності інституту, його підрозділів та окремих викладачів .

Першу групу праць, відповідно до проблемно-хронологічного принципу умовно можна поділити два етапи:

$$
\begin{array}{ll}
\checkmark & \text { перший }-1930-1991 \text { pp.; } \\
\checkmark & \text { другий }-1991-2020 \text { рр. }
\end{array}
$$

Праці, опубліковані на першому етапі, здебільшого мали партійнополітичний відтінок, у них ідеалізувалася політика радянської влади в галузі освіти та їі позитивні досягнення. В історичних дослідженнях вищі навчальні заклади педагогічного спрямування, науково-педагогічні колективи, радянське студентство розглядали як носії комуністичної ідеології та помічники партії в соціалістичному будівництві. 3’явилися дослідження історії окремих навчальних закладів. У працях другого етапу дослідники зосереджували увагу на проблемах історії вищої педагогічної школи та ії ролі в соціально-політичній структурі суспільства в умовах його реформування. Усе більше робіт присвячують історії закладів вищої освіти та їх структурних підрозділів, вивчають їх наукові доробки, деякі аспекти навчально-методичної діяльності.

Характерною особливістю історіографії першого періоду $\epsilon$ те, що предметом наукового аналізу ставали процеси реформування всієї системи вищої школи. Монографії, колективні праці, статті збагачувалися новим фактичним матеріалом, a питання розвитку вищої педагогічної освіти вписувалося в загальний процес культурного будівництва в СРСР. Здебільшого виклад матеріалу мав некритичний характер i в основному висвітлював досягнення в освітянській сфері. Для аналізу освітньої практики автори широко використовували ленінські праці, давали коментарі та оцінки в дусі марксистсько-ленінського вчення.

У 1932 р. з’явилася праця О. Дзеверіна «Шляхи радянської школи за заповітами В. І. Леніна» (Дзеверін, 1932). в якій автор у дусі епохи тоталітаризму висвітлює становлення радянської системи освіти в контексті ідей В.І. Леніна. Здобутки радянської системи педосвіти відображено у статті I. Хлівного «Педагогічна освіта за 15 років» (1932 р.) (Бєляєва та ін., 2007). Цим та іншим працям періоду 1930-1950-х рр. притаманна цензура держави та партійної номенклатури, нав’язування науковцям принципів радянської ідеології (Ящук, 2013).

Тенденційними та заідеологізованими були й праці С. Бухала «Освіта в радянській Україні», М. М. Грищенка «Розвиток народної освіти на Україні за роки радянської влади», С. Чавдарова «Тридцять років радянської школи в УРСР». Вони показують діяльність закладів вищої освіти як низку перемог і не містять аналізу їі стану і проблем.

Практично всі праці цього періоду про освіту й виховання були заідеологізовані й тенденційні, носили характер лозунгів і пропаганди, вихваляли політику Й. Сталіна. Яскравим прикладом можуть слугувати праці Г. Пінчука «Сталінське піклування про народну освіту» (1950р.), О. Філіпова «35 років розвитку радянської школи на Україні» (1952 р.). I хоча вони мають суб’єктивний характер, все ж є частиною історіографії української освіти й 
виховання і варті на певну увагу (Ящук, 2013).

Серед робіт про загальну діяльність радянської народної освіти, відзначимо дослідження М. М. Грищенка в колективній роботі «Розвиток народної освіти і педагогічної науки в Українській РСР» (Розвиток народної освіти, 1957). У статті «Сорок років розвитку радянської школи в Українській РСР» показано позитивні зміни в народній освіті України за роки радянської влади, проте питання діяльності педагогічних ЗВО, підготовки педагогічних кадрів не були окремою проблемою досліджень. Якщо й згадували ці питання, то лише в плані покращення контингенту педагогічних кадрів у школах України, без аналізу матеріалу та визначення сильних і слабких сторін підготовки їх у педінститутах республіки, не пропонували шляхів поліпшення системи педагогічної освіти.

У другій половині 1950-х рр. змінилася політична ситуація в країні, що вплинуло і на зміст досліджень історії вищої педагогічної освіти, яких переважно висвітлюють здобутки як безперечні досягнення під керівництвом партії, не виходять за межі ідеології та партійних доктрин; статті позбавлені критичності та об'єктивності.

Варта уваги робота М. С. Гриценка, яка стосувалася розвитку радянської школи в Україні. Автор іï намагався показати «великі перетворення в галузі народної освіти» за 40 років радянської влади. У четвертому розділі йдеться про підготовку педагогічних кадрів та роботу радянського учительства. На основі статистичних даних автор вказує на значне збільшення контингенту учителів за роки радянської влади, а особливе зростання, на 120 тис. осіб, відбулося в післявоєнний час. Не аналізуючи проблеми підготовки педагогічних кадрів, автор здебільшого констатує на досягненнях (Розвиток народної освіти, 1957). Аналізу роботи педагогічних навчальних закладів, зокрема й Уманського, не подано.

У 1960-х роках вийшли у світ спеціальні видання, у яких вивчалися питання існуючої системи народної освіти й підготовки педагогічних кадрів в Україні. У притаманній для того часу манері в роботах возвеличувалися досягнення радянської влади в галузі розвитку народної освіти. Їм характерні такі тогочасні риси, як суб'єктивізм в оцінці подій та результатів освітянських реформ. Автори здебільшого вказували на досягнення, не аналізуючи хід цих перетворень, особливо в питаннях становлення й розвитку системи формування педагогічних кадрів, не критично оцінювали їх результати та вдавалися до лакування існуючої системи педагогічної освіти.

Це узагальнювальні праці, В. Пітова «Высшая школа Украинской ССР в период перестройки» (1962р.), М. Лескевича «Розвиток вищої педагогічної школи в Українській РСР за 1917-1967» (1967р.), колективній монографії «Народна освіта і педагогічна наука в Українській РСР 1917-1967» (1967р.) та «Вища школа УРСР за 50 років» (1967р.), монографія М. Ніжинського «Школа, учитель, педагогіка. Історичний нарис» (1978 р.) (Ящук, 2013).

Наприкінці 60-х років було видано фундаментальне дослідження про розвиток вищої освіти в Українській РСР за 50 років радянської влади у двох частинах. Перша частина стосувалася періоду 1917-945 pp., а друга частина - 
1945-1967 рр. (Вища школа. Ч. 1., 1967; Вища школа. Ч. 2., 1968). У роботі показано формування широкої мережі різногалузевих закладів вищої освіти Української РСР. Автори не обійшли увагою діяльність педагогічних навчальних закладів. Здебільшого йшлося про створення оптимальної мережі учительських та педагогічних інститутів у післявоєнний час. На початку 50-х років значна частина учительських інститутів (Кам'янець-Подільський, Кременчуцький, Станіславський, Дрогобицький, Бердичівський, Глухівський, Осипенківський, Рівненський, Ізмаїльський, Луцький, Слов'янський, Уманський) реорганізовано в педагогічні. Усі учительські інститути при педінститутах були об'єднані з ними. Частину учительських інститутів, які не мали достатньої навчально-матеріальної бази та кадрового потенціалу або знаходилися в містах, де вже були педагогічні 3ВО, було ліквідовано: Лебединський, Одеський, Харківський, Київський, Артемівський, Конотопський, Старобільський, Ужгородський. Великим досягненням радянської влади в галузі освіти автори монографії називали значне зростання контингенту студентів, що відбувалося у 1960 -х роках. Характеризуючи зміни в навчальному процесі та досягнення в науці вищої школи, автори монографії зосереджують увагу на провідних галузевих навчальних закладах та класичних університетах, не згадуючи Уманський державний педагогічний інститут. Проте, незважаючи на значну цінність цієї праці зауважимо, що вона виконана в дусі радянської доби та ідеології, поряд зі значним фактологічним матеріалом усе представлено у світлі перемог та досягнень партії й радянського суспільства, відсутня критична оцінка подій та фактів.

У 60 - 80-ті роки XX ст. більше уваги приділялося питанням історії вищої школи, оскільки з'явилося розуміння важливості їі ролі в соціально-політичній структурі суспільства в умовах його формування. Науковці почали досліджувати проблеми історії вищої школи взагалі і вищої педагогічної освіти зокрема, насамперед з'ясовуючи особливості їх розвитку. Були зроблені спроби вивчення історії окремих ЗВО, серед них і Уманський педагогічний інститут. Такі публікації присвячувалися ювілейним датам навчальних закладів для показу успішного вирішення питань культурного будівництва.

Серед праць, про історію вищої педагогічної освіти України, виокремимо дисертаційні дослідження (Журжа, 2006). I хоч у частині дисертацій зосереджено увагу на 3'ясуванні педагогічної проблематики, проте в них переважає історико-партійне висвітлення досягнень радянської влади i правлячої партії в галузі народної освіти. Підготовка педагогічних кадрів, історія навчальних закладів згадується лише в загальних рисах, зокрема в статистичних даних як ілюстративному матеріалі.

На увагу заслуговують наближені до тематики нашого дослідження праці В. Я. Серобаби, але освіта в них відображена здебільшого через статистичні дані про загальну кількість студентів закладів вищої освіти, їх фінансування, а також охарактеризовано роботу Київського університету імені Тараса Шевченка (Серебаба, 1986; Серебаба, 1987; Серебаба, 1988; Серебаба, 1989; Серебаба, 1990).

3 початку 90-х років XX ст. ситуація в історіографії цієї тематичної групи 
різко змінилася, з'явилися публікації про проблеми, що раніше не досліджувалися, кардинально змінилися оцінка подій та підходи у їх висвітленні, з'явилося поняття «білі плями» в історії, а у зв'язку з цим визріли нові завдання в історичній науці. Головною особливістю цього періоду став відхід науковців від марксистсько-ленінської методології й партійно-класового підходу до аналізу суспільних явищ і подій. Широке використання нових, закритих у радянські часи архівних документів привело до прагнення переосмислити процес становлення й розвитку радянської системи вищої педагогічної освіти.

У цей же період 3'являються роботи українських дослідників, які на основі узагальнення і систематизації нових архівних матеріалів, вивчають різні аспекти розвитку вищої педагогічної освіти. У наукових монографіях та статтях розглядають проблеми організації та управління всієї системи педагогічної освіти, структури ЗВО, форми і методи роботи, підготовку науковопедагогічних кадрів.

Серед перших історичних праць цього періоду - дослідження Р. Кігеля та Ю. Рарога, які розглядають правові основи вищої освіти, державну політику в галузі науки, та праці Л. Герасіної, М. Добрускіної, А. Мурашка, Є. Петрова та ін., присвячені організації наукової роботи, хоча їм притаманні суперечливі підходи та прагнення звинуватити у всіх прорахунках радянську владу (Січкаренко, 2020).

На основі нових джерел дослідники вивчають історію закладів вищої освіти, формування їх навчально-матеріальної бази, реорганізації структури, напрямки наукової діяльності, підготовку професорсько-викладацьких кадрів тощо. Це праці, присвячені Київському педагогічному інституту (Київський інститут, 1990), Івано-Франківському педінситуту та ін. (Івано-Франківський інститут, 1990).

Історія, досвід та уроки розвитку вищої педагогічної освіти в Україні представлені в дослідженнях В. К. Майбороди та С. В. Майбороди (Майборода, 1990; Майборода, 1992; Майборода, 1990). У роботі В. К. Майбороди вперше в хронологічній послідовності з'ясовано стан та розвиток вищої педагогічної освіти від 1917 р. до 1985 р. Починаючи з другого розділу, автор вивчає питання реорганізації і розвитку закладів вищої педагогічної освіти, зокрема й Уманського педагогічного інституту та інших інститутів у системі педагогічної освіти. На основі значної кількості архівних матеріалів у книзі подано порівняльні таблиці про кількість існуючих на різні періоди часу шкіл, учнів та учителів, показано динаміку контингенту студентів залежно від потреб школи. Значне місце в монографії відведено вивченню питань підвищення рівня загальноосвітньої і професійної підготовки студентів педагогічних навчальних закладів.

У 2009-2013 рр. за ініціативою Національної академії педагогічних наук України, Асоціації ректорів педагогічних університетів Європи, Інституту вищої освіти України у видавництві «Знання України» видрукувано серію книг, присвячених аналізу розвитку педагогічної освіти і науки в Україні на тлі історичного розвитку, природничо-географічних і економічних умов (Вища 
освіта, 2010). У них розкрито багатство інтелектуально-культурного потенціалу регіонів у єдності з розвитком науки і культури. Простежено історію розвитку педагогічної освіти в областях, здійснено аналіз сучасних іiі проблем та визначено іiі перспективи.

Серед спеціальних праць інтерес викликає монографія Г. Г. Січкаренка «Історичний досвід перебудови вищої освіти в Україні (1985-2005 рр.)» (2005 р.), у якій автор відобразив основні напрямки трансформації вищої освіти, проаналізував реформи вищої освіти в роки перебудови (Січкареноко, 2014) У брошурі Г. Касьянова «Освітня система України 1900-2010. Аналітичний огляд» (2015р.) подано загальний огляд освітньої системи України та основних проблем освітнього простору (Касьянов, 2015).

У 2002 р. вийшла друком праця Г. С. Червичного, у якій комплексно охарактеризовано стан вищої освіти в Україні в другій половині 1980-х років. Монографіï багата на фактологічний матеріал та авторські підрахунки (Черевичний, 2002).

Особливої уваги заслуговує науковий доробок О. В. Лук’яненка. Учений досліджує різні аспекти життя колективів викладачів та студентів закладів вищої педагогічної освіти Української РСР. У монографії «”Найближчі друзі партії”: колективи педагогічних закладів вищої освіти України в образах щодення 1920-х - першої половини 1960-х років» (2019 р.) автор комплексно дослідив повсякдення колективів педагогічних закладів вищої освіти радянської України в 1920-1960-х роках, на різноманітній джерельній базі відтворив дозвілля, проаналізував життя колективів цих закладів у період Голодомору 1932-1933 pp., німецько-радянської війни 1941-1945 pp. та окупації (Лист Міністерства освіти, 2005).

За останні роки історіографія про діяльність інститутів вищої педагогічної освіти поповнилася значною кількістю досліджень, присвячених окремим ЗВО та закладам вищої педагогічної освіти, зокрема Дрогобицького, Кам'янець-Подільського, Переяслав-Хмельницького, Бердянського, Луганського, Київського та інших (70 років Дрогобицькому університету, 2010; Завальнюк, 2007; Історія української культури, 2011; Кралюк, 2013; Курило, 2011; Крижко, 2008; Самойленко, 1999; Південноукраїнський університет, 2007; Харківський університет, 2001; Херсонський університет, 2007; Черкаський інститут, 1991; Черкаський університет, 2009; Ювілейна книга, 2004) розглядаючи низку проблем становлення та розвитку радянської вищої педагогічної школи, дослідники розкривають особливості освітньої системи, їі структури i фінансування, організацію навчального процесу, формування педагогічних кадрів тощо.

Для розуміння соціально-економічних, суспільно-політичних і культурних процесів, що мали місце в радянській та незалежній Україні неабияке значення для нас мають загальні праці українських істориків. 3 проголошенням незалежності України з'явилися нові можливості, пов'язані із відходом від комуністичної ідеології та доступом до архівних джерел.

У цьому контексті виокремимо шеститомне видання «Політичної історії України» (тт. 3, 4, 6) (Політична історія. Т. 1., 2003; Політична історія. Т. 2., 
2003; Політична історія. Т. 3., 2003), п’ятитомне видання «Історія української культури» (т. 5) (Історія української культури, 2011), де йдеться, зокрема про заідеологізованість та уніфікованість підходів до проблеми освіти, про іiі жорсткий партійний контроль та політизацію. Заслуговують на увагу й праці С. В. Кульчицького, В. К. Барана і В. М. Даниленка та ін. (Алексєєв та ін., 2000; Баран, 1999; Даниленко, 1991; Кульчицький, 1999; Уряди України, 2001).

Друга група - праці, присвячені історії Уманського державного педагогічного університету імені Павла Тичини, у яких розглядають окремі періоди діяльності інституту, його підрозділів та окремих викладачів. Зауважимо, що об'єктивного аналізу проблем підготовки педагогічних кадрів в окремих навчальних закладах не було, дослідження проводили за такими напрямами:

1) вивчення широкого кола суміжних питань, пов'язаних 3 соціалістичним будівництвом, розвитком народної освіти та формуванням нової радянської інтелігенції;

2) вивчення окремих галузей науки та їх розвитку;

3) у період відзначення ювілеїв друкувались історії окремих ЗВО.

Перша стаття з історії Уманського учительського інституту 1930-1947 pp., була надрукована тодішнім директором навчального закладу М. Б Шакала (Шакало, 1947), та іншими викладачами інституту в одному із перших випусків збірника «Наукові записки Уманського учительського інституту» (Уманський інститут, 1947). У ній подано відомості про історію інституту.

У 1980 р. 3'являється перший друкований нарис з історії Уманського педагогічного інституту, приурочений 50-річчю навчального закладу. Відповідальним редактором був Б. Н. Товбіс - завідувач кафедри марксизмуленінізму (Уманський інститут, 1980). Ця невелика за обсягом робота має цінний матеріал для нашого дослідження. Головною її метою було показати читачу півстолітню історію навчального закладу. Започаткований як інститут соціального виховання у 1930 р., він пройшов складний шлях радянських реформувань: інститут соціального виховання - 1930 р., педагогічний інститут - 1933 р., учительський - 1935 р. 31952 р. за рішенням Колегії Міністерства освіти УРСР був реорганізований у педагогічний. У 1967 р. Уманському педагогічному інституту присвоєно ім'я П. Г. Тичини. Автори нарису коротко показали основні етапи розвитку педагогічного навчального закладу в м. Умань. У стилі того часу основну увагу вони акцентували на його досягненнях.

Окремі етапи історії Уманського педагогічного університету висвітлено у колективній праці «Вища педагогічна освіта i наука України: історія, сьогодення та перспективи розвитку. Черкаська область» (Вища педагогічна освіта, 2010). Серед педагогічних навчальних закладів Черкащини у загальних рисах охарактеризовано й діяльність Уманського ЗВО.

Відзначимо окремі брошури з історії УДПІ ім. П. Г. Тичини, приурочені до 60-річного та 65-річного ювілеїв інституту, у 1990 р. та 1995 р. відповідно. Це наступні після 1980 р. спроби написання історії інституту, проте власне 
історії присвячені лише невеликі розділи, а вся увага зосереджена на здобутках інституту (Балдинюк та ін., 1990; Кузь та ін., 1995).

Зауважимо, що всі вище згадані публікації з історії інституту готували не професійні історики, а спеціалісти з педагогічної науки та інші співробітники інституту чи журналісти згаданих видань.

Окремі згадки про Уманський інститут соціального виховання знаходимо в статті О. Б. Комарніцького «Педагогічні навчальні заклади Черкащини 20-30ті pp. XX ст.: реорганізації та формування студентського складу» (Комарніцький, 2013).

Висновки. Історіографічний аналіз дає можливість зробити висновок, що в радянській та українській історичній літературі немає комплексного дослідження історії Уманського педагогічного університету, проте накопичено певний матеріал та зроблені перші спроби подати деякі аспекти з його історії. Склалися необхідні передумови для цілісної характеристики політики влади у сфері вищої педагогічної освіти, вивчені лише окремі епізоди становлення структурних підрозділів інституту, науково-педагогічної діяльності професорсько-викладацького складу тощо. Але ці напрацювання не вичерпують тему дослідження, а навпаки потребують комплексної і всебічної розробки, що надасть глибини вивченню історії УДПІ в багатьох площинах.

Завершуючи історіографічний огляд проблеми, слід зазначити, що всі згадані публікації $\epsilon$ надзвичайно цінним історичним джерелом 3 огляду первинної інтерпретації та систематизації великої кількості матеріалу 3 визначеної теми, але деякі дані та висновки, які містяться в них, потребують уточнення, переосмислення і переоцінки 3 позицій новітнього наукового підходу до української історії.

\section{СПИСОК ВИКОРИСТАНИХ ДЖЕРЕЛ І ЛІТЕРАТУРИ}

70 років Дрогобицькому університету, 2010 - 70 років Дрогобицькому педагогічному університету імені Івана Франка. Молодь і ринок. 2010. № 9. С 5-7.

Алексєєв та ін., 2000 - Алексєєв Ю.М., Кульчицький С.В., Слюсаренко А.Г. Україна на зламі історичних епох: Державотворчий процес 1985-1999 рр.: Навч. посіб. К.: ЕксОб, 2000. 296 с.

Балдинюк та ін., 1990 - Уманський державний педагогічний інститут імені П.Г. Тичини: 1930-1990 / Авт. Д.І. Балдинюк, Н.М. Бріт, Г.О. Казидуб, І.Е. Каньковський, А.О. Карасевич, М.В. Картель, О.М. Коберник, Ю.М. Краснобокий, С.С. Крохмаль, В.Г. Кузь, І.С. Лозебний, І.Я. Лисий, М.Т. Мартинюк, Ю.І. Молотковський, А.К. Ткаченко; МОН Української РСР. Умань, 1990. 27 с.

Баран, 1999 - Баран В.К., Даниленко В.М. Україна в умовах системної кризи (1946-1980-і рр.) / Серія «Україна крізь віки» (т. 13). Київ: Вид. дім «Альтернативи», 1999. 304 с.

Вища педагогічна освіта, 2010 - Вища педагогічна освіта і наука України: історія, сьогодення та перспективи розвитку. Черкаська область /[ред. рада вид.: В.Г. Кремень (гол.) [та ін.]; редкол. тому: А.І. Кузьмінський (гол.) [та ін.]. К.: Знання України, 2010. 351 с.

Вища школа. Ч. 1., 1967 - Вища школа Української РСР (1917-1967 pp.): у 2-х частинах / за ред. В.І. Пітова. К.: Вид-во Київського університету, 1967. Ч. 1.: 1917-1945 pp. 395 с.

Вища школа. Ч. 2., 1967 - Вища школа Української РСР (1917-1967 рр.): у 2-х частинах / за ред. В.І. Пітова. К.: Вид-во Київського університету, 1968. Ч. 2.: 1945-1967 pp. 540 с.

Даниленко, 1991 - Даниленко В.М., Касьянов Г.В., Кульчицький С.В. Сталінізм на Україні: 20-30-ті роки. К.: Либідь, 1991. 344 с.

Дзеверін, 1932 - Дзеверін О. Шляхи радянської школи за заповітами В.І. Леніна. Харків : Радянська школа, 1932. $47 \mathrm{c.}$

Журжа, 2006 - Журжа І.В. Становлення та розвиток слов'янознавства в Університеті св. Володимира (18341919 рр.): автореф. дис... канд. іст. наук: 07.00.06. К., 2006. 237 с.

Завальнюк, 2007 - Завальнюк О.М. Кам’янець-Подільський національний університет(1918-2008 рр.): 
історичний нарис. К. Подільськ: Абетка нова, 2007. 227 с.

Івано-Франківський інститут, 1990 - Івано-Франківський державний педагогічний інститут імені В.С. Стефаника (Документальний нарис) / відп. за вип. П.С. Федорчак. Ужгород: Карпати, 1990. 120 с.

Історія української культури, 2011 - Історія української культури [Текст] : у 5 т. Т. 5 , кн. 2 : Українська культура XX - початку XXI століть / [Агеєва В.П. та ін.]; редкол. тому, кн. 2 : Жулинський М.Г. - голов. ред. [та ін.]. К, 2011. 1031 с.

Касьянов, 2015 - Касьянов Г. Освітня система України 1990-2014 Аналітичний огляд. / Благодійний фонд «Інститут розвитку освіти». К.: ТАКСОН, 2015. 52 с.

Київський університет, 1990 - Київський державний педагогічний університет імені М.П. Драгоманова 19201995: іст. нарис. / П.П. Хропко, О.Г. Лозовицький. К.: Просвіта: ТОВ «Толока», 1995. 169 с.

Комарніцький, 2013 - Комарніцький О.Б. Педагогічні навчальні заклади Черкащини у 20-30-ті pp. ХХ ст.: реорганізації та формування студентського складу. Наукові праці Кам'янець-Подільського національного університету імені Івана Огієнка. Історичні науки. 2013. Т. 23. С. 416-424.

Кралюк, 2013 - Кралюк П.М. Острозька академія в філософській культурі України: монографія. Острог: Видавництво Національного університету «Острозька академія», 2013. 482 с.

Крижко, 2008 - Крижко В. Бердянський державний педагогічний університет. Слово $і$ час. 2008. №2. С. 3.

Кузь та ін., 1995 - Уманський державний педагогічний інститут імені П.Г. Тичини: 1930-1995 / уклад. В.Г. Кузь, О.М. Коберник, М.М. Торчинський ; МОН України. Умань: [Мрія], 1995. 63 с.

Кульчицький, 1999 - Кульчицький С.В. Україна між двома війнами (1921-1939 рр.) / За заг. ред. В. Смолія. НАН України. Інститут історії України. К.: Альтернативи, 1999. 336 с.

Курило, 2011 - Курило В. Створення та розвиток першого педагогічного ВНЗ Донбасу: до 90-річчя Луганського національного університету імені Тараса Шевченка). Рідна школа. 2011. №1/2. С. 33-39.

Лист Міністерства освіти, 2005 - Лист Міністерства освіти і науки України «Про основні завдання вищим навчальним закладам на 2005-2006 навчальний рік». К.: Знання, 2005. 15 с.

Майборода, 1990 - Майборода В.К. 3 історії становлення і розвитку педагогічної освіти на Україні (19281941 рр.). Початкова школа. 1990. № 12. С. 34-36.

Майборода, 1990 - Майборода В.К. Особливості розвитку системи вищої педагогічної освіти в УРСР (19171941 рр.). Украӥнський історичний журнал, 1990. № 11. С. 58-64.

Майборода, 1992 - Майборода В.К. Вища педагогічна освіта в Україні: історія, досвід, уроки (1917-1985 рр.). К.: Либідь, 1992. 196 с.

Південноукраїнський університет, 2007 - Південноукраїнський державний педагогічний університет ім. К.Д. Ушинського. 1817-2007: історичний поступ. Сучасність. Майбутнє / [ред. рада: О.Я. Чебикін (гол.), І.Г. Захарченко, Н.В. Яблонська та ін.; авт.: О.Я. Чебикін, І.А. Болдирєв, А.О. Добролюбський та ін.]. Одеса: Друк. дім «Фаворит», 2007. 240 с.

Політична історія. Т. 1., 2003- Політична історія України. ХХ ст. : у 6 т. Т. 4 : Україна у Другій світовій війні (1939-1945) / В.І. Кучер [та ін.]. [Б. м.] : [б.в.], 2003. 584 с.

Політична історія. Т. 2., 2003 - Політична історія України. ХХ ст. [Текст] : у 6 т. Т. 6 : Від тоталітаризму до демократії (1945-2002) / О.М. Майборода [та ін.]. К. : [б.в.], 2003. 696 с.

Політична історія. Т. 3., 2003 - Політична історія України. ХХ ст.: у 6 т. Т. 3 : Утверження радянського ладу в Україні (1921-1938) / В. А. Греченко [та ін.]. [Б. м.] : [б.в.], 2003. 448 с.

Розвиток народної освіти, 1957 - Розвиток народної освіти і педагогічної науки в Українській РСР (1917-1957). К.: Радянська школа, 1957. 448 с.

Самойленко, 1999 - Самойленко Г.В., Самойленко О.Г. Ніжинський державний педагогічний університет імені Миколи Гоголя. Ніжин: Ніжин. держ. пед. ун-т ім. М. Гоголя, 1999. 278 с.

Серебаба, 1986 - Серобаба В.Я. Советская Украина. Киев: Политиздат Украины, 1986. 120 с.

Серебаба, 1987 - Серобаба В.Я. Советская Украина. Киев: Политиздат Украины, 1987. 72 с.

Серебаба, 1988 - Серобаба В.Я. Советская Украина. Киев: Политиздат Украины, 1988. 88 с.

Серебаба, 1989 - Серобаба В.Я. Советская Украина. Киев: Политиздат Украины, 1989. 88 с.

Серебаба, 1990 - Серобаба В.Я. Советская Украина. Киев: Политиздат Украины, 1990. 80 с.

Січкаренко, 2020 - Січкаренко Г.Г. Дослідження розвитку вищої освіти в Україні (1990-ті pp.). Biсник Східноукраїнського національного університету імені Володимира Даля. 2020. №3 (259). С. 82.

Січкареноко, 2014 - Січкаренко Г.Г. Історичний досвід перебудови вищої освіти в Україні (1985-2005 рр.): монографія. Ніжин: Видавець ПП Лисенко М.М., 2014. 360 с.

Уманський інститут, 1947 - Уманський державний учительський інститут. Наукові записки [Уманського учительського інституту]. 1947. 56 с.

Уманський інститут, 1980 - Уманський державний педагогічний інститут імені П.Г. Тичини: 1930-1980 / Відп. ред БН. Товбіс. Умань : [Уманська міська друкарня], 1980. 15 с.

Уряди України, 2001 - Уряди України у ХХ ст. / С.В. Кульчицький [та ін] ; відп. ред. В.М. Литвин ; Кабінет Міністрів України, НАН України. К. : Наукова думка, 2001. 608 с.

Харківський університет, 2001 - Харківський державний педагогічний університет ім. Г.С. Сковороди / [за заг. ред. І.Ф. Прокопенка]. Харків: ОВС, 2001. 176 с.

Херсонський університет, 2007 - Херсонський державний університет: іст. нарис (1917-2007) / авт. кол.: Ю.І. Бєляєва, О.В. Мішуков, В.Л. Федяєва, І.В. Самсакова. Херсон: Херсон. держ. ун-т, 2007. 352 с. 
Черевичний, 2002 - Черевичний Г.С. Вища освіта в Україні на зламі епох (1985-1991 рр.): монограф. Київ: ІВЦ Держкомстату України, 2002. 122 с.

Черкаський інститут, 1991 - Черкаський державний педагогічний інститут / укладач О.Г. Перехрест. Черкаси, 1991.338 c.

Черкаський університет, 2001 - Черкаський державний університет імені Богдана Хмельницького. Історичний нарис. 1921-2001. К.:АртЕк, 2001. 128 с.

Черкаський університет, 2009 - Черкаський національний університет імені Богдана Хмельницького. Історія. Звершення. Особистості / [редкол.: А.І. Кузьмінський (гол.), В.І. Бойко, Л.В. Швидка та ін.]. Київ: Світ успіху, 2009. $208 \mathrm{c}$.

Шакало, 1947 - Шакало М.Б. Уманський державний учительський інститут. Наукові записки [Уманського учительського інституту]. 1947. С. 3-10.

Ювілейна книга, 2004 - Ювілейна книга: Житомирському державному університету імені Івана Франка - 85 років: іст. нарис / авт.: П.Ю. Саух, В.В. Власенко, О.А. Дубасенюк та ін. Житомир: Косенко, 2004. 232 с.

Ящук, 2013 - Ящук І.П. Виховання майбутніх педагогів у вищому педагогічному навчальному закладі (19201991 рр.) як предмет історико-педагогічного дослідження. Педагогічний дискурс. 2013. Вип. 15. C. 794. URL: http://nbuv.gov.ua/UJRN/peddysk_2013_15_162 (дата звернення 01.12.2021 ).

\section{REFERENCES}

70 rokiv Drohobytskomu universytetu, 2010 - 70 rokiv Drohobytskomu pedahohichnomu universytetu imeni Ivana Franka. Molod i rynok [70 years of Drohobych Pedagogical University named after Ivan Franko]. 2010. № 9. S 5-7. [in Ukrainian].

Aleksieiev ta in., 2000 - Aleksieiev Yu.M., Kulchytskyi S.V., Sliusarenko A.H. Ukraina na zlami istorychnykh epokh: Derzhavotvorchyi protses 1985-1999 rr.: Navch. posib. [Ukraine at the turn of historical epochs . (State-building process 1985-1999)] K.: EksOb, 2000. 296 s. [in Ukrainian].

Baldyniuk ta in., 1990 - Umanskyi derzhavnyi pedahohichnyi instytut imeni P.H. Tychyny: 1930-1990 [Uman State Pedagogical Institute named after PG Ticini: 1930-1990] / Avt. D.I. Baldyniuk, N.M. Brit, H.O. Kazydub, I.E. Kankovskyi, A.O. Karasevych, M.V. Kartel, O.M. Kobernyk, Yu.M. Krasnobokyi, S.S. Krokhmal, V.H. Kuz, I.S. Lozebnyi, I.Ya. Lysyi, M.T. Martyniuk, Yu.I. Molotkovskyi, A.K. Tkachenko; MON Ukrainskoi RSR. Uman, 1990. 27 s. [in Ukrainian].

Baran, 1999 - Baran V.K., Danylenko V.M. Ukraina v umovakh systemnoi kryzy (1946-1980-i rr.) / Seriia «Ukraina kriz viky» (t. 13) [Vol. 13 : Ukraine in the systemic crisis (1946-1980)]. Kyiv: Vyd. dim «Alternatyvy», 1999. 304 s. [in Ukrainian].

Vyshcha pedahohichna osvita, 2010 - Vyshcha pedahohichna osvita i nauka Ukrainy: istoriia, sohodennia ta perspektyvy rozvytku. Cherkaska oblast [Higher pedagogical education and science of Ukraine : history, present and prospects of development. Cherkasy region] /[red. rada vyd.: V.H. Kremen (hol.) [ta in.]; redkol. tomu: A.I. Kuzminskyi (hol.) [ta in.]. K.: Znannia Ukrainy, 2010. 351 s. [in Ukrainian].

Vyshcha shkola. Ch. 1., 1967 - Vyshcha shkola Ukrainskoi RSR (1917-1967 rr.): u 2-kh chastynakh [Higher School of the Ukrainian SSR (1917-1967): in 2 parts] / za red. V.I. Pitova. K.: Vyd-vo Kyivskoho universytetu, 1967. Ch. 1.: 1917-1945 rr. 395 s. [in Ukrainian].

Vyshcha shkola. Ch. 2., 1967 - Vyshcha shkola Ukrainskoi RSR (1917-1967 rr.): u 2-kh chastynakh [Higher School of the Ukrainian SSR (1917-1967): in 2 parts] / za red. V.I. Pitova. K.: Vyd-vo Kyivskoho universytetu, 1968. Ch. 2.: 1945-1967 rr. 540 s. [in Ukrainian].

Danylenko, 1991 - Danylenko V.M., Kasianov H.V., Kulchytskyi S.V. Stalinizm na Ukraini: 20-30-ti roky [Stalinism in Ukraine: 20-30s]. K.: Lybid, 1991. 344 s. [in Ukrainian].

Dzeverin, 1932 - Dzeverin O. Shliakhy radianskoi shkoly za zapovitamy V.I. Lenina [Ways of the Soviet school by the will of V.I. Lenin]. Kharkiv: Radianska shkola, 1932. 47 s. [in Ukrainian].

Zhurzha, 2006 - Zhurzha I.V. Stanovlennia ta rozvytok slov'ianoznavstva v Universyteti sv. Volodymyra (1834-1919 rr.) [Formation and development of Slavic studies at the University of St. Vladimir (1834 - 1919)]: avtoref. dys... kand. ist. nauk: 07.00.06. K., 2006. 237 s. [in Ukrainian].

Zavalniuk, 2007 - Zavalniuk O.M. Kam'ianets-Podilskyi natsionalnyi universytet(1918-2008 rr.): istorychnyi narys [Kamyanets-Podilsky National University (1918-2008): historical essay]. K. Podilsk: Abetka nova, 2007.227 s. [in Ukrainian].

Ivano-Frankivskyi instytut, 1990 - Ivano-Frankivskyi derzhavnyi pedahohichnyi instytut imeni V.S. Stefanyka (Dokumentalnyi narys) [Ivano-Frankivsk State Pedagogical Institute named after V.S. Stefanika (Documentary essay)] / vidp. za vyp. P.S. Fedorchak. Uzhhorod: Karpaty, 1990. 120 s. [in Ukrainian].

Istoriia ukrainskoi kultury, 2011 - Istoriia ukrainskoi kultury [History of Ukrainian culture]: u 5 t. T. 5 , kn. 2 : Ukrainska kultura XX - pochatku XXI stolit / [Aheieva V.P. ta in.] ; redkol. tomu, kn. 2 : Zhulynskyi M.H. - holov. red. [ta in.]. K, 2011. 1031 s. [in Ukrainian].

Kasianov, 2015 - Kasianov H. Osvitnia systema Ukrainy 1990-2014 Analitychnyi ohliad [Educational system of Ukraine , 1990 - 201: analyst. review]. / Blahodiinyi fond «Instytut rozvytku osvity». K.: TAKSON, 2015.52 s. [in Ukrainian].

Kyivskyi universytet, 1990 - Kyivskyi derzhavnyi pedahohichnyi universytet imeni M.P. Drahomanova 1920-1995: ist. 
narys. [Ukrainian State Pedagogical University named after MP Dragomanova 1920-1995: East. sketch.] / P.P. Khropko, O.H. Lozovytskyi. K.: Prosvita: TOV «Toloka», 1995. 169 s. [in Ukrainian].

Komarnitskyi, 2013 - Komarnitskyi O.B. Pedahohichni navchalni zaklady Cherkashchyny u 20-30-ti rr. KhKh st.: reorhanizatsii ta formuvannia studentskoho skladu [Pedagogical educational institutions of Cherkasy region in the 2030 s of the XX century: reorganization and formation of student staff]. Naukovi pratsi Kam'ianets-Podilskoho natsionalnoho universytetu imeni Ivana Ohiienka. Istorychni nauky . 2013. T.23. S. 416-424. [in Ukrainian].

Kraliuk, 2013 - Kraliuk P.M. Ostrozka akademiia v filosofskii kulturi Ukrainy : monohrafiia [Ostroh Academy in the Philosophical Culture of Ukraine: monograph]. Ostroh : Vydavnytstvo Natsionalnoho universytetu «Ostrozka akademiia», 2013. 482 s. [in Ukrainian].

Kryzhko, 2008 - Kryzhko V. Berdianskyi derzhavnyi pedahohichnyi universytet [Berdyansk State Pedagogical University]. Slovo i chas. 2008. №2. S. 3. [in Ukrainian].

Kuz ta in., 1995 - Umanskyi derzhavnyi pedahohichnyi instytut imeni P.H. Tychyny: 1930-1995 [Uman State Pedagogical Institute named after P.G. Ticini: 1930-1995] / uklad. V.H. Kuz, O.M. Kobernyk, M.M. Torchynskyi ; MON Ukrainy. Uman: [Mriia], 1995. 63 s. [in Ukrainian].

Kulchytskyi, 1999 - Kulchytskyi S.V. Ukraina mizh dvoma viinamy (1921-1939 rr.) [Ukraine between the two wars (1921 - 1939)] / Za zah. red. V. Smoliia. NAN Ukrainy. Instytut istorii Ukrainy. K.: Alternatyvy, 1999. 336 s. [in Ukrainian].

Kurylo, 2011 - Kurylo V. Stvorennia ta rozvytok pershoho pedahohichnoho VNZ Donbasu: do 90 richchia Luhanskoho natsionalnoho universytetu imeni Tarasa Shevchenka) [Creation and development of the first pedagogical university of Donbass : to the 90th anniversary of Lugansk National University named after Taras Shevchenko)]. Ridna shkola. 2011. №1/2. S. 33-39. [in Ukrainian].

Lyst Ministerstva osvity, 2005 - Lyst Ministerstva osvity i nauky Ukrainy «Pro osnovni zavdannia vyshchym navchalnym zakladam na 2005-2006 navchalnyi rik» [Letter of the Ministry of Education and Science of Ukraine «On the main tasks of higher educational institutions for the 2005/2006 academic year»]. K.: Znannia, 2005.15 s. [in Ukrainian].

Maiboroda, 1990 - Maiboroda V.K. Z istorii stanovlennia i rozvytku pedahohichnoi osvity na Ukraini (1928-1941 rr.) [From the history of formation and development of pedagogical education in Ukraine (1928-1941)]. Pochatkova shkola. 1990. № 12. S. 34-36. [in Ukrainian].

Maiboroda, 1990 - Maiboroda V.K. Osoblyvosti rozvytku systemy vyshchoi pedahohichnoi osvity v URSR (1917-1941 rr.) [Features of the development of the system of higher pedagogical education in the USSR (1917-1941)]. Ukrainskyi istorychnyi zhurnal, 1990. №11. S. 58-64. [in Ukrainian].

Maiboroda, 1992 - Maiboroda V.K. Vyshcha pedahohichna osvita v Ukraini: istoriia, dosvid, uroky (1917-1985 rr.) [Higher pedagogical education in Ukraine: history, experience, lessons (1917-1985)]. K.: Lybid, 1992.196 s. [in Ukrainian].

Pivdennoukrainskyi universytet, 2007 - Pivdennoukrainskyi derzhavnyi pedahohichnyi universytet im. K.D. Ushynskoho. 1817-2007: istorychnyi postup. Suchasnist. Maibutnie [South Ukrainian State Pedagogical University named after KD Ushinsky. 1817-2007: historical progress, present, future] / [red. rada: O.Ya. Chebykin (hol.), I.H. Zakharchenko, N.V. Yablonska ta in.; avt.: O.Ya. Chebykin, I.A. Boldyriev, A.O. Dobroliubskyi ta in.]. Odesa: Druk. dim «Favoryt», 2007. 240 s. [in Ukrainian].

Politychna istoriia. T. 1., 2003- Politychna istoriia Ukrainy. XX st. [Political history of Ukraine . XX century] : u 6 t. T. 4 : Ukraina u Druhii svitovii viini (1939-1945) / V.I. Kucher [ta in.]. [B. m.] : [b.v.], 2003. 584 s. [in Ukrainian].

Politychna istoriia. T. 2., 2003 - Politychna istoriia Ukrainy. XX st. [Political history of Ukraine . XX century]: u 6 t. T. 6 : Vid totalitaryzmu do demokratii (1945-2002) / O.M. Maiboroda [ta in.]. K. : [b.v.], 2003. 696 s. [in Ukrainian].

Politychna istoriia. T. 3., 2003 - Politychna istoriia Ukrainy. XX st. [Political history of Ukraine . XX century]: u 6 t. T. 3 : Utverzhennia radianskoho ladu v Ukraini (1921-1938) / V. A. Hrechenko [ta in.]. [B. m.] : [b.v.], 2003. 448 s. [in Ukrainian].

Rozvytok narodnoi osvity, 1957 - Rozvytok narodnoi osvity i pedahohichnoi nauky v Ukrainskii RSR (1917-1957) [Development of public education of Ukrainian SSR (1917-1957)]. K.: Radianska shkola, 1957. 448 s. [in Ukrainian].

Samoilenko, 1999 - Samoilenko H.V., Samoilenko O.H. Nizhynskyi derzhavnyi pedahohichnyi universytet imeni Mykoly Hoholia [Nizhyn State Pedagogical University named after Mykola Gogol]. Nizhyn: Nizhyn. derzh. ped. un-t im. M. Hoholia, 1999. 278 s. [in Ukrainian].

Serebaba, 1986 - Serobaba V.Ya. Sovetskaia Ukrayna [Soviet Ukraine]. Kyev: Polytyzdat Ukraynd, 1986. 120 s. [in Russian].

Serebaba, 1987 - Serobaba V.Ya. Sovetskaia Ukrayna [Soviet Ukraine]. Kyev: Polytyzdat Ukraynы, 1987. 72 s. [in Russian].

Serebaba, 1988 - Serobaba V.Ya. Sovetskaia Ukrayna [Soviet Ukraine]. Kyev: Polytyzdat Ukraynы, 1988. 88 s. [in Russian].

Serebaba, 1989 - Serobaba V.Ya. Sovetskaia Ukrayna [Soviet Ukraine]. Kyev: Polytyzdat Ukraynы, 1989. 88 s. [in Russian].

Serebaba, 1990 - Serobaba V.Ya. Sovetskaia Ukrayna [Soviet Ukraine]. Kyev: Polytyzdat Ukraynы, 1990. 80 s. [in Russian].

Sichkarenko, 2020 - Sichkarenko H.H. Doslidzhennia rozvytku vyshchoi osvity v Ukraini (1990-ti rr.) [Researches of 
higher education development in Ukraine (1990s)]. Visnyk Skhidnoukrainskoho natsionalnoho universytetu imeni Volodymyra Dalia. 2020. №3 (259). S. 82. [in Ukrainian].

Sichkarenoko, 2014 - Sichkarenko H.H. Istorychnyi dosvid perebudovy vyshchoi osvity v Ukraini (1985-2005 rr.): monohrafiia [Historical experience of perestroika of higher education in Ukraine (1985-2005): monograph]. Nizhyn: Vydavets PP Lysenko M.M., 2014. 360 s. [in Ukrainian].

Umanskyi instytut, 1947 - Umanskyi derzhavnyi uchytelskyi instytut [Uman State Teachers' Institute]. Naukovi zapysky [Umanskoho uchytelskoho instytutu]. 1947. 56 s. [in Ukrainian].

Umanskyi instytut, 1980 - Umanskyi derzhavnyi pedahohichnyi instytut imeni P.H. Tychyny: 1930-1980 [Uman State Pedagogical Institute named after P.G. Ticini: 1930-1980] / Vidp. red BN. Tovbis. Uman : [Umanska miska drukarnia], 1980. 15 s. [in Ukrainian].

Uriady Ukrainy, 2001 - Uriady Ukrainy u XX st. [Governments of Ukraine in the XX century.] / S.V. Kulchytskyi [ta in] ; vidp. red. V.M. Lytvyn ; Kabinet Ministriv Ukrainy, NAN Ukrainy. K. : Naukova dumka, 2001. 608 s. [in Ukrainian].

Kharkivskyi universytet, 2001 - Kharkivskyi derzhavnyi pedahohichnyi universytet im. H.S. Skovorody [Kharkiv State Pedagogical University named after GS Skovorodi] / [za zah. red. I.F. Prokopenka]. Kharkiv: OVS, 2001.176 s. [in Ukrainian].

Khersonskyi universytet, 2007 - Khersonskyi derzhavnyi universytet: ist. narys (1917-2007) [Kherson State University: historical essay (1917-2007)] / avt. kol.: Yu.I. Bieliaieva, O.V. Mishukov, V.L. Fediaieva, I.V. Samsakova. Kherson: Kherson. derzh. un-t, 2007. 352 s. [in Ukrainian].

Cherevychnyi, 2002 - Cherevychnyi H.S. Vyshcha osvita v Ukraini na zlami epokh (1985-1991 rr.): monohraf [Higher education in Ukraine at the turn of the epochs (1985-1991)]. Kyiv: IVTs Derzhkomstatu Ukrainy, 2002.122 s.

Cherkaskyi instytut, 1991 - Cherkaskyi derzhavnyi pedahohichnyi instytut [Cherkasy State Pedagogical Institute] / ukladach O.H. Perekhrest. Cherkasy, 1991. 338 s. [in Ukrainian].

Cherkaskyi universytet, 2001 - Cherkaskyi derzhavnyi universytet imeni Bohdana Khmelnytskoho. Istorychnyi narys [Bohdan Khmelnytsky National University of Cherkasy. Historical essay]. 1921-2001. K.:ArtEk, 2001.128 s. [in Ukrainian].

Cherkaskyi universytet, 2009 - Cherkaskyi natsionalnyi universytet imeni Bohdana Khmelnytskoho. Istoriia. Zvershennia. Osobystosti [Bohdan Khmelnytsky National University of Cherkasy. History. Accomplishment. Personality] / [redkol.: A.I. Kuzminskyi (hol.), V.I. Boiko, L.V. Shvydka ta in.]. Kyiv: Svit uspikhu, 2009. 208 s. [in Ukrainian].

Shakalo, 1947 - Shakalo M.B. Umanskyi derzhavnyi uchytelskyi instytut [Uman State Teachers' Institute]. Naukovi zapysky [Umanskoho uchytelskoho instytutu]. 1947. S. 3-10. [in Ukrainian].

Yuvileina knyha, 2004 - Yuvileina knyha: Zhytomyrskomu derzhavnomu universytetu imeni Ivana Franka - 85 rokiv: ist. narys [Jubilee book : Zhytomyr State University named after Ivan Franko - 85 years [Text]: historical essay] / avt.: P.Yu. Saukh, V .V. Vlasenko, O.A. Dubaseniuk ta in. Zhytomyr: Kosenko, 2004. 232 s. [in Ukrainian].

Yashchuk, 2013 - Yashchuk I.P. Vykhovannia maibutnikh pedahohiv u vyshchomu pedahohichnomu navchalnomu zakladi (1920-1991 rr.) yak predmet istoryko-pedahohichnoho doslidzhennia [Education of future teachers in higher pedagogical educational institution (1920-1991) as a subject of historical and pedagogical research]. Pedahohichnyi dyskurs. 2013. Vyp. 15. S. 794. URL: http://nbuv.gov.ua/UJRN/peddysk_2013_15_162 (data zvernennia (01.12.2021 ). [in Ukrainian]. 